\title{
Morphological Differences among Apple Leaf Types
}

\author{
I. Schechter ${ }^{1}$, J.T.A. Proctor ${ }^{2}$, and D.C. Elfving ${ }^{3}$ \\ Department of Horticultural Science, University of Guelph, Guelph, Ont. \\ N1G 2W1, Canada
}

Additional index words. shoot leaves, fruiting and nonfruiting spur leaves, Malus domestica

\begin{abstract}
Leaf characteristics of mature 'Sturdeespur Delicious'/MM.106 apple trees (Malus domestica Borkh.) were studied in two experiments. In 1989 canopy foliage on fruiting trees was divided into shoot leaves, leaves on nonfruiting spurs, and leaves on fruiting spurs. Shoot leaves were the heaviest, the largest, and contained the highest internal gas volume and chlorophyll content. The two spur-leaf types differed in their leaf characteristics except for stomate density. In 1990 shoot and spur leaves on nonfruiting spurs on fruiting trees had lower leaf water content than those leaves on nonfruiting trees. All other shoot-leaf characteristics were similar. Leaves on nonfruiting spurs on nonfruiting trees were larger than those on fruiting trees.
\end{abstract}

The net photosynthesic $(\mathrm{Pn})$ rate in plants is determined by many interrelated factors: environmental, morphological, and physiological. The internal structure of apple leaves is well adapted for photosynthesis due to the well-developed palisade parenchyma tissue densely populated with chloroplasts (MacDaniels and Cowart, 1944). Cultivar and structural differences in the apple leaf were described by Picket $(1933,1934)$ and Picket and Kenworthy (1939). Comparison of spurtype cultivars with their parent types suggested that the spur-type had a thicker palisade parenchyma, higher leaf dry matter content, and more chlorophyll (Chl) per leaf area than the standard cultivars (Looney, 1968).

Schechter et al. (1991a) reported that shoot leaves had the highest Pn rate per leaf area, while spur leaves on fruiting spurs had the lowest. In several studies, shoot leaves had Pn rates of 16\% (Schechter et al., 1991a), $10 \%$ to $22 \%$ (Watson and Landsberg, 1979), $31 \%$ (Watson et al., 1978), and up to $300 \%$ higher during August and September (Palmer, 1986) than leaves on fruiting spurs.

Our study was undertaken to investigate the effect of fruiting on morphological characteristics of various apple leaf types.

'Sturdeespur Delicious' MM.106 trees were planted in 1977 in Simcoe, Ont., in northsouth rows at a spacing of $3 \times 5 \mathrm{~m}(667$ trees/ha) on. a moderately well-drained

\footnotetext{
Received for publication 20 May 1991. Accepted for publication 27 Sept. 1991. This research was supported by operating grant no. A6697 of the Natural Sciences and Engineering Research Council of Canada held by J.T.A.P. We gratefully acknowledge the assistance received from Dean Louttit. The cost of publishing this paper was defrayed in part by the payment of page charges. Under postal regulations, this paper therefore must be hereby marked advertisement solely to indicate this fact.

Graduate Student.

${ }^{2}$ Professor.

${ }^{3}$ Manager, Research Programs, Horticultural Research Institute of Ontario, Vineland Station, Ont.
} LOR 2E0, Canada.
Walsher soil composed of 40 to $100 \mathrm{~cm}$ of sandy loamy material over glaciolacustrine clay. The trees were trained to a conventional central-leader form. For purposes of this experiment, three leaf categories were identified in the canopy: shoot leaves $(\mathrm{SH})$, spur leaves on nonfruiting spurs $(\mathrm{S}-\mathrm{F})$, and spur leaves on fruiting spurs $(S+F)$. Shoot leaves were taken from new terminal and lateral growth originating from the previous season's shoots. Bourse shoots, few in number in this cultivar, were not used. Nonfruiting spur leaves were sampled from spurs that did not bloom, or did not set fruit, or from which the fruit dehisced before the time of June drop. Leaves on fruiting spurs were collected from spurs carrying one to three fruit. Leaves were taken from 2- to 4-yearold spurs that were well exposed. On 22 Aug. 1989, 50 leaves from each leaf category were collected from five average cropping trees (80 kg of fruit/tree). On 12 Aug. 1990, 20 $\mathrm{SH}$ and $\mathrm{S}-\mathrm{F}$ leaves were harvested from four heavy-cropping trees in a completely randomized design (128 and $83 \mathrm{~kg}$ of fruit/ tree in 1989 and 1990, respectively) and from four deblossomed trees that bore no fruit in 1989 and 1990. Leaves were collected under sunny conditions between 1000 to $1200 \mathrm{HR}$.

Thirteen leaf characteristics (Table 1) were measured in 1989 and 1990. Fully expanded, sun-exposed leaves of the three categories, collected as above, were sealed in nylon bags in ice-cooled containers while being transported from the field to the laboratory for fresh weight (FW) measurements after petioles were removed. Leaf area was measured using a LI-3000 area meter (LI-COR, Lincoln, Neb.) fitted with a LI-3053 transparent belt accessory.

Leaf chlorophyll (Chl) content was estimated using a SPAD-501 (Minolta Corp. Ramsey, N.J.) portable leaf greenness meter calibrated against Chl content (Yadava, 1986). A large range of SPAD-501 readings was obtained from fully expanded, healthy, turgid, and flat leaves (Yadava, 1986), collected in the orchard, ranging from light green to a very deep dark green. For each leaf, a 1.5.cm-diameter tissue disk was punched from each side of the midrib and leaf greenness was estimated from three SPAD-501 readings per disk. Then the disks were extracted in boiling ethanol $(80 \%)$ (Wintermans and deMoto, 1965) and Chl $a$ and $\mathrm{Chl} b$ were determined using a DU-8 spectrophotometer (Beckman Corp., Fullerton, Calif.). A strong correlation $\left(r^{2}=0.94, \mathrm{n}=25\right)$ between the extractable $\mathrm{Chl}$ and the SPAD readings was observed. The Chl content of leaves sampled in 1989 and 1990 was estimated from their SPAD readings using this relationship.

To determine total leaf volume and internal gas volume, a technique based on Archimedes' principle (Raskin, 1983) measured the buoyant force acting on leaves submerged in liquid. After a leaf was weighed in air $(\mathrm{FW})$, it was dipped in a $0.05 \%(\mathrm{v} / \mathrm{v})$ aqueous solution of surfactant (Triton X-100); this precaution prevented air bubbles from adhering to the leaf surface when submerged in water and avoided an overestimation of leaf volume. The leaf weight was then determined in distilled water $\left(\mathrm{p}_{\text {water }}=1.0\right.$ $\mathrm{g} \cdot \mathrm{cm}^{-3}$ ) by suspending the leaf from a wire and leaf clamp connected to a built-in hook on the bottom of a pretared (1.0 mg sensitivity) electronic pan balance (PE 360, Mettler Instrument Corp., Hightstown, N.J.). Finally, the leaf was placed in a desiccator, totally submerged in a Triton X-100 $0.05 \%$ (v/v) solution. A vacuum of $\approx 500 \mathrm{~mm} \mathrm{H}_{\mathrm{s}}$ was applied for $30 \mathrm{sec}$ and released three times while the tissue was being agitated. The infiltrated leaf was then reweighed submerged in water as described above. Following these procedures, leaves were placed in an oven at $80 \mathrm{C}$ and dried to a constant weight. Leaf water content (LWC) on a dry-weight (DW) basis (Ackley, 1964) was calculated. Leaf thickness was calculated from area and volume data (Raskin, 1983).

Stomate size and density were estimated by microscopic measurements and counting of stomata on leaf epidermal replicas on cellulose-acetate film (Raschke, 1970). Since apple leaves are hypostomatous, leaf impressions of the abaxial surface only were obtained by placing a drop of undiluted acetone on the surface of the leaf and pressing a 3 $\times 3-\mathrm{cm}$ strip of colorless acetate onto it for $10 \mathrm{~min}$. Separate leaf samples (15 leaves/leaf type) were taken, and two interveinal zones in the central portion of the leaf (Cowart, 1935) were used for this subexperiment after confirming that there was no systematic variation in stomatal density over the leaf surface (Slack, 1974). The means of two stomate counts and 10 width-by-length measurements of open stomata were used in the statistical analysis.

In 1989, significant differences among the leaf-types means for variables used were assessed and compared using Duncan's new multiple range test $(P=0.05)$ following analysis of variance (ANOVA). In 1990, data were subjected to ANOVA, with sources of variance including treatment (fruiting vs. deblossomed trees), leaf type ( $\mathrm{SH}$ vs. S - F), and the interaction of these two factors. The 
Table 1. Apple leaf type $(\mathrm{SH}=$ shoot, $\mathrm{S}-\mathrm{F}=$ spur - fruit, $\mathrm{S}+\mathrm{F}=$ spur + fruit $)$ characteristics in 1989 .

\begin{tabular}{|c|c|c|c|c|c|c|}
\hline \multirow[b]{2}{*}{ Leaf characteristics $^{\mathbf{z}}$} & \multicolumn{6}{|c|}{ Leaf type } \\
\hline & \multicolumn{2}{|c|}{ SH } & \multicolumn{2}{|c|}{$S-F$} & \multicolumn{2}{|c|}{$S+F$} \\
\hline Fresh wt (mg) & 981 & a & 501 & $\bar{b}$ & 288 & $\bar{c}$ \\
\hline Dry wt (mg) & 406 & a & 210 & b & 126 & $\mathrm{c}$ \\
\hline Leaf water content ( $\%$ dry wt) & 142 & a & 141 & a & 131 & b \\
\hline Area $\left(\mathrm{mm}^{2}\right)$ & 3567 & a & 2311 & b & 1518 & c \\
\hline Specific leaf wt $\left(\mathrm{mg} \cdot \mathrm{mm}^{-2}\right)$ & 0.1 & a & 0. & $9 \mathbf{b}$ & & $3 c$ \\
\hline Volume $\left(\mathrm{mm}^{3}\right)$ & 885 & a & 422 & $\mathrm{~b}$ & 231 & c \\
\hline Density $\left(\mathrm{mg} \cdot \mathrm{mm}^{-3}\right)$ & 1.1 & $\mathrm{c}$ & 1. & $1 \mathrm{~b}$ & & $5 \mathrm{a}$ \\
\hline Thickness (mm) & 0.2 & & 0. & $8 \mathrm{~b}$ & & $5 \mathrm{c}$ \\
\hline Internal gas volume $\left(\mathrm{mm}^{3}\right)$ & 145 & a & 66 & $\mathrm{~b}$ & 45 & c \\
\hline Chlorophyll $a\left(\mu \mathrm{g} \cdot \mathrm{cm}^{-2}\right)$ & 37 & a & 33 & b & 31 & c \\
\hline Chlorophyll $b\left(\mu \mathrm{g} \cdot \mathrm{cm}^{-2}\right)$ & 15 & a & 13 & b & 11 & c \\
\hline Total chlorophyll $\left(\mu \mathrm{g} \cdot \mathrm{cm}^{-2}\right)$ & 52 & a & 46 & $\mathrm{~b}$ & 42 & c \\
\hline Stomate density (no. $/ \mathrm{mm}^{2}$ ) & 430 & $a$ & 356 & b & 366 & b \\
\hline
\end{tabular}

"Means separation within leaf characteristics by Duncan's new multiple range test at $P=0.05$. Each value is the mean of 50 leaves, except for stomate number, which contains 15 observations.

Table 2. The effect of fruiting on apple leaf characteristics of shoot leaves and spur leaves on nonfruiting spurs in 1990.

\begin{tabular}{|c|c|c|c|c|}
\hline \multirow[b]{2}{*}{ Leaf characteristics } & \multicolumn{2}{|c|}{ Shoot leaves ${ }^{\mathrm{z}}$} & \multicolumn{2}{|c|}{ Spur leaves ${ }^{2}$} \\
\hline & $F^{y}$ & $\mathrm{NF}^{\mathrm{y}}$ & $F^{y}$ & NFy \\
\hline Fresh wt (mg) & 769 & 817 & $300^{*}$ & 390 \\
\hline Dry wt (mg) & 354 & 352 & 154 & 175 \\
\hline Leaf water content (\% dry wt) & $117^{* *}$ & 133 & $93^{* *}$ & 122 \\
\hline Area $\left(\mathrm{mm}^{2}\right)$ & 2950 & 3134 & $1450^{*}$ & 1818 \\
\hline Specific leaf wt $\left(\mathrm{mg} \cdot \mathrm{mm}^{-2}\right)$ & 0.12 & 0.11 & 0.10 & 0.10 \\
\hline Volume $\left(\mathrm{mm}^{3}\right)$ & 679 & 692 & 252 & 315 \\
\hline Density $\left(\mathrm{mg} \cdot \mathrm{mm}^{-3}\right)$ & 1.14 & 1.18 & 1.21 & 1.24 \\
\hline Thickness (mm) & 0.23 & 0.22 & 0.17 & 0.17 \\
\hline Internal gas volume $\left(\mathrm{mm}^{3}\right)$ & 157 & 156 & 69 & 82 \\
\hline Chlorophyll $a\left(\mu \mathrm{g} \cdot \mathrm{cm}^{-2}\right)$ & 40 & 38 & 38 & 39 \\
\hline Chlorophyll $b\left(\mu \mathrm{g} \cdot \mathrm{cm}^{-2}\right)$ & 18 & 16 & 16 & 17 \\
\hline Total chlorophyll $\left(\mu \mathrm{g} \cdot \mathrm{cm}^{-2}\right)$ & 58 & 54 & 54 & 56 \\
\hline
\end{tabular}

${ }^{2}$ Each mean contains 20 observations.

${ }^{\mathrm{y}} \mathrm{F}=$ Fruiting trees; $\mathrm{NF}=$ nonfruiting trees.

***Mean separations within leaf type and leaf characteristics by $t$ test at $P=0.05$ or 0.01 , respectively.

nonsignificant interaction term $(\mathrm{P}=0.05)$ was pooled with the error sum of squares in a reduced model. Comparison of the treatment for SH leaves and S - F leaves (by leaf) was done separately, and the $t$ test was used for testing significance.

Leaf types (1989). Shoot leaves were twice as heavy as S - F leaves (FW and DW), and about three times heavier than $\mathrm{S}+\mathrm{F}$ leaves (Table 1). The $S-F$ leaves were about twice the weight (FW and DW) of the $\mathrm{S}+\mathrm{F}$ leaves. The S - F leaf area was $60 \%$ of the SH leaf area, while S + F was $40 \%$ of the SH leaf area. The difference in area between the two spur-leaf types was $35 \%$. A similar trend was reported for the mean of four apple cultivars (Cowart, 1935) and for 'Red Delicious' trees on various rootstocks (Schechter, 1989). Generally, SH leaves contribute proportionally more to leaf area than to leaf count on a tree (Forshey et al., 1987; Schechter et al., 1991b). Photosynthetic data are often reported on a leaf area basis. However, when Pn is reported on an individual leaf, a whole canopy DW, or Chl basis (Flore and Lakso, 1989), the large contribution of $\mathrm{SH}$ leaves to the tree carbon budget becomes apparent.

A leaf can be characterized by specific leaf weight (SLW). In general, as SLW increases, the Pn rate also increases (Barden, 1977, 1978). Our data, which consisted only
Cowart, 1935; Looney, 1968). Leaf thickness was correlated with SLW and Chl content per unit of leaf area and lead to a higher shoot leaf photosynthetic rate (Ghosh, 1973).

Chlorophyll a content was about two to three times more than Chl $b$ (Table 1), in agreement with Kramer and Kozlowski (1979). Chloroplasts congregate in a single layer on the cell wall/air interface, so that the greater leaf thickness with larger internal gas volume of the shoot leaves may explain the differences in total Chl per unit of leaf area among leaf types. Although not conclusive, leaf Pn was correlated to leaf Chl concentrations (Lakso and Lenz, 1986).

Stomate density was higher for SH leaves, while the similar density for the two spurleaf types probably stems from their common origin and time of development (Table 1). Leaves with higher stomaten density offer a larger area of $\mathrm{CO}_{2}$ intake. In contrast to our findings, Cowart (1935) reported similar stomate density for the three leaf types. Stomata averaged $\approx 20 \mathrm{~km}$ wide and $30 \mu \mathrm{m}$ long in all leaf types, similar to the values reported by MacDaniels and Cowart (1944). Higher internal gas volume coupled with greater stomatal frequency in SH leaves may lead to greater stomatal and mesophyll $\mathrm{CO}_{2}$ conductance and help to explain the higher Pn capability observed under saturated light conditions (Schechter et al., 1991a).

Differences in leaf volume and density were consistent with other differences in leaf characteristics (Table 1).

Fruiting vs. nonfruiting trees (1990). Leaf water content was the only SH leaf characteristic that differed between fruiting and nonfruiting trees; i.e., nonfruiting $\mathrm{SH}$ leaves had the higher LWC (Table 2). Spur leaves on the nonfruiting trees were heavier, larger, and had higher LWC than those leaves on nonfruiting spurs on nonfruiting trees (Table 2). The difference in FW for the two leaf types, along with the similar DW, is reflected in the LWC differences.

Apple leaves on cropping trees in pots had higher LWC than leaves on nonfruiting trees (Monselise and Lenz, 1980). On the contrary, but similar to our findings, Erf and Proctor (1987) suggested that leaves on the nonfruiting, mature, field-grown trees contained more water than leaves on cropping trees. Fruiting did not affect the SH leaf area in 'McIntosh' trees, but the spur-leaf area was smaller (Forshey and Marmo, 1985). In the present study, this was the trend found for SH leaves, and spur-leaves, in agreement with Singh (1948). Smaller spur leaves may be a result of more sinks competing in spring for reserves on the cropping trees, while later, when shoot leaves develop, cropping affected the number and the length of the shoots (Forshey, 1982; Maggs, 1963) without significantly affecting their size (Forshey and Marmo, 1985).

The photosynthetic capability of different apple leaf types was demonstrated by Palmer (1986), Schechter et al. (1991a), Watson et al. (1978), and Watson and Landsberg (1979). Although leaf age effects on Pn rate are not conclusive (Flore and Lakso, 1989), visual 
assessments, 2 years of seasonal Pn measurements for those trees, and reports of Ferree and Palmer (1982) and Schechter et al. (1991a) focus attention on a 25- to 30-day difference between spur-leaf and shoot-leaf development. Shoot leaves located at the canopy periphery are more directly exposed to sunlight and for a longer time, especially during leaf development, when the environmental conditions, along with abundant carbohydrates, nutrients, and water, favor leaf development in comparison to those existing in early spring. Stomata1 development on SH leaves was completed faster than in spur leaves (Slack, 1974). Rom and Ferree (1986) hypothesized that the simultaneous development of SH leaves and fruit might have exposed them to hormonal and assimilatedemand signals. It is also probable that shoot stems have more water vessels than spurs; thus, the increase in water supply results in greater leaf thickness due to the development of the palisade tissue. Leaves on $\mathrm{S}+\mathrm{F}$, which develop under intense carbohydrate competition with flower buds, blossoms, and later fruitlets, became the smallest leaves.

\section{Literature Cited}

Ackley, W.B. 1964. Seasonal and diurnal changes in the water contents and water deficits of 'Bartlett' pear leaves. Plant Physiol. 29:445-448.

Barden, J.A. 1977. Apple tree growth. net photosynthesis, dark respiration, and specific leaf weight as affected by continuous and intermittent shade. J. Amer. Soc. Hort. Sci. 102:391394.

Barden, J.A. 1978. Apple leaves, their morphology and photosynthetic potential. HortScience 13:644-646.

Beakbane, A.B. 1967. A relationship between leaf structure and growth potential in apple. Ann. Applied Biol. 60:67-76.

Cowart, F.F. 1935. Apple leaf structure as related to position of the leaf upon the shoot and type of growth. Proc. Amer. Hort. Sci. 33:145-148.

Erf, J.A. and J.T.A. Proctor. 1987. Changes in apple leaf water status and vegetative growth as influenced by crop load. J. Amer. Soc. Hort. Sci. 112:617-620.

Ferree, D.C. and J.W. Palmer. 1982. Effect of spur defoliation and ringing during bloom on fruiting, fruit mineral level, and net photosynthesis of 'Golden Delicious' apple. J. Amer. Soc. Hort. Sci. 107:1182-1186.

Flare, J.A. and A.N. Lakso. 1989. Environmental and physiological regulation of photosynthesis in fruit crops. Hort. Rev. 11:111-157.

Forshey, C.G. 1982. Effects of fruiting, pruning, and nitrogen fertilization on shoot growth of 'Empire' apple trees. J. Amer. Soc. Hort. Sci. 107:1092-1097.

Forshey, C.G. and C.A. Marmo. 1985. Pruning and deblossoming effects on shoot growth and leaf area of 'McIntosh' apple trees. J. Amer. Soc. Hort. Sci. 110:128-132.

Forshey, C.G., R.W. Weires, and J.R. VanKirk. 1987. Seasonal development of the leaf canopy of 'Macspur McIntosh' apple trees. HortScience 22:881-883.

Ghosh, S.P. 1973. Internal structure and photosynthetic activity of different leaves of apple. J. Hort. Sci. 48:1-9.

Kaiser, W.M. 1982. Correlation of changes in photosynthetic activity and changes in total protoplast volumes in leaf tissue from hygro-, mesoand xerophytes under osmotic stress. Planta 154:538-546.

Kramer, P.J. and T.T. Kozlowski. 1979. Physiology of woody plants. Academic, New York.

Lakso, A.N. and F. Lenz. 1986. Regulation of apple tree photosynthesis in the autumn by temperature, p. 34-37. In: A. Lakso and F. Lenz (eds.). The regulation of photosynthesis in fruit trees. New York State Agr. Expt. Sta. Spec. Publ., Geneva.

Looney, N.E. 1968. Comparison of photosynthetic efficiency of two apple cultivars with their compact mutants. Proc. Amer. Soc. Hort. Sci. 92:34-36.

MacDaniels, L.H. and F.F. Cowart. 1944. The development and structure of the apple leaf. Memoir Cornell Univ. Agr. Expt. Sta. 258:129

Maggs, D.H. 1963. The reduction in growth of apple trees brought about by fruiting. J. Hort. Sci. 38:119-128.

Monselise, S.P. and F. Lenz. 1980. Effect of fruit load on photosynthetic rates of budded apple trees. Gartenbauwissenschaften 45:220-224.

Palmer, J.W. 1986. Seasonal variation of light saturated photosynthetic rate of 'Golden delicious' apple leaves as influenced by leaf type and crop load, p. 30-33. In: Lakso and F. Lenz (eds.). The regulation of photosynthesis in fruit trees. New York State Agr. Expt. Sta., Spec. Publ., Geneva.

Picket, W.F. 1933. A comparative study of the intercellular spaces of apple leaves. Proc. Amer. Soc. Hort. Sci. 30:156-161.

Picket, W.F. 1934. Photosynthetic activity and internal structure of apple leaves are unrelated. Proc. Amer. Soc. Hort. Sci. 32:81-85.

Picket, W.F. and A.L. Kenworthy. 1939. The re- lationship between structure, chlorophyll content and photosynthesis in apple leaves. Proc. Amer. Soc. Hort. Sci. 37:371-373.

Raschke, K. 1970. Stomatal response to pressure changes and interruption in the water supply of detached leaves of Zea mays L. Plant Physiol. 45:415-423.

Raskin, I. 1983. A method for measuring leaf volume, density, thickness, and internal gas volume. HortScience 18:698-699.

Rom, C.R. and D.C. Ferree. 1986. Influence of fruit on spur leaf photosynthesis and transpiration of 'Golden Delicious' apple. HortScience 21:1026-1029.

Schechter, I. 1989. Apple tree light interception, photosynthesis, growth and yield as affected by different apple rootstocks. MS Thesis, Univ. of Guelph, Guelph, Ont.

Schechter, I., D.C. Elfving, and J.T.A. Proctor. 1991a. Apple tree canopy development and photosynthesis as affected by rootstock. Can. J. Bot. 69:295-300.

Schechter, I., D.C. Elfving, and J.T.A. Proctor. 1991b. Rootstock effect on vegetative growth characteristics and productivity in 'Delicious' apple. HortScience 26(9):1145-1148.

Schulze, E.D. 1986. Carbon dioxide and water vapor exchange in response to drought in the atmosphere and in the soil. Annu. Rev. Plant Physiol. 37:247-274.

Singh, L.B. 1948. Studies in biennial bearing. III. Growth studies in "on" and "off' year trees. J. Hort. Sci. 24:123-148.

Slack, E.M. 1974. Studies of stomatal distribution on the leaves of four apple varieties. J. Hort. Sci. 49:95-103.

Watson, R.L., J.J. Landsberg, and M.R. Thorpe 1978. Photosynthetic characteristics of the leaves of 'Golden Delicious' apple. Plant, Cell Environ. 1:51-58.

Watson, R.L. and J.J. Landsberg. 1979. The photosynthetic characteristics of apple leaves (cv. Golden Delicious) during their early growth, $\mathrm{p}$. 39-48. In: R. Marcelle, H. Clijsters, and M. Van Poucke (eds.). Photosynthesis and plant development. W. Junk, The Hague, The Netherlands.

Wilson, D. and J.P. Cooper. 1970. Effect of selection for mesophyll cell size on growth and assimilation in Lolium perenne L. New Phytol. 69:233-245.

Wintermans, J.F.G.M. and A. deMoto. 1965. Spectrophotometric characteristics of chlorophyll $a$ and $b$ and their pheophytins in ethanol. Biochem. \& Biophys. Acta 109:448-453.

Yadava, U.L. 1986. A rapid nondestructive method to determine chlorophyll in intact leaves. HortScience 21:1449-1450. 